\section{THE DIFFICULTIES AND MISTAKES IN THE DIFFERENTIAL DIAGNOSTICS OF TUBERCULOUS MENINGOENCEPHALITIS OF CHILD AGED 6,5 MONTHS}

M.B. Dasho, C.A. Lyshenyuk, U.B. Chulovska, H.O. Lytvyn

SUMMARY. In the context of differential diagnostics of acute infectious lesions of the CNS the case of tuberculous meningoencephalitis was analyzed in the child's first year of life at all stages of its development from the tuberculosis of lungs to a generalized form of the central nervous system (CNS) and the reasons that led to the late (posthumous) diagnostics of this disease. Key words: tuberculosis, children, acute neuroinfections, meningitis, encephalitis, clinic, diagnostics.

Отримано 18.03.2016 p.

DOI

\author{
М.А. Андрейчин
}

\title{
НАГОРОДНА МЕДАЛЬ ВСЕУКРАЇНСЬКОЇ АСОЦІАЦІЇ ІНФЕКЦІОНІСТІВ ДЛЯ МЕДИЧНИХ СЕСТЕР
}

Тернопільський державний медичний університет ім. І.Я. Горбачевського

Всеукраїнська асоціація інсрекціоністів (BAI) - громадська самоврядна організація, яка об'єднує на добровільних засадах лікарів-інфекціоністів. Вона була створена у травні 1997 року на установчих зборах в м. Полтава. Спочатку звалась Асоціацією інфекціоністів України. Перейменована на теперішню назву згідно з вимогою Закону України «Про громадські об'єднання» (2012р.).

За нашим поданням, 1 вересня 2015 року президія BAI прийняла «Положення про нагородження пам'ятною медаллю Святого Роха» медичних сестер інфекційних лікарень (відділень) і кабінетів інфрекційних захворювань поліклінік.

Рох належить до найбільш відомих і шанованих у християнському світі святих. Визнаний покровителем інсекційних хворих і захисником від епідемій. Свого часу (XIII ст.) він проявив надзвичайну жертовність і відвагу, працюючи на півдні Франції та в Італії в епідемічних осередках чуми. Надаючи допомогу хворим, сам заразився i, ймовірно, переніс бубонну фрорму чуми.

Згідно з «Положенням...», пам'ятною медаллю Святого Роха BAl нагороджує медичних сестер лікувальнопрофрілактичних закладів інфекційного профілю за милосердя та профресіоналізм, багаторічну сумлінну працю. Основні критерії відбору кандидата такі:
1. Обласний осередок (відокремлений підрозділ BAI) може пропонувати 1-2 кандидатури, м. Київ і область - 3.

2. Претендент повинен мати не менше 20 років професійного стажу роботи з інсрекційними хворими і бездоганну службову характеристику. Кандидатури мають пройти обговорення і затвердження шляхом голосування на засіданні обласного осередку.

3. Витяг з протоколу засідання осередку подається до президії BAI не пізніше, ніж за 10 днів до чергового з'їзду BAI із зазначенням прізвища, імені, по батькові, посади і місця роботи претендента.

4. Нагородженому або голові обласного осередку інфекціоністів (за відсутності нагородженої особи) медаль і посвідчення вручає президент BAI на найближчому з'їзді інсрекціоністів України.

5. Уповноважений голова обласного осередку зобов'язаний вручити нагородженій особі медаль і посвідчення в найближчий місяць на зібранні колективу.

Медаль створив львівський медальєр Богуслав Петрович Гриник, виготовило ТзОВ «Штука». Вона діаметром 51 мм, з латуні, покритої позолотою. Організаційні клопоти на себе взяв секретар BAІ доцент О.Л. Івахів.

У центрі аверсу цієї вишуканої медалі художник розмістив рельєфний, дещо повернутий вправо анфрас Роха 3 


\section{КОРОТКІ ПОВІДОМЛЕННЯ}
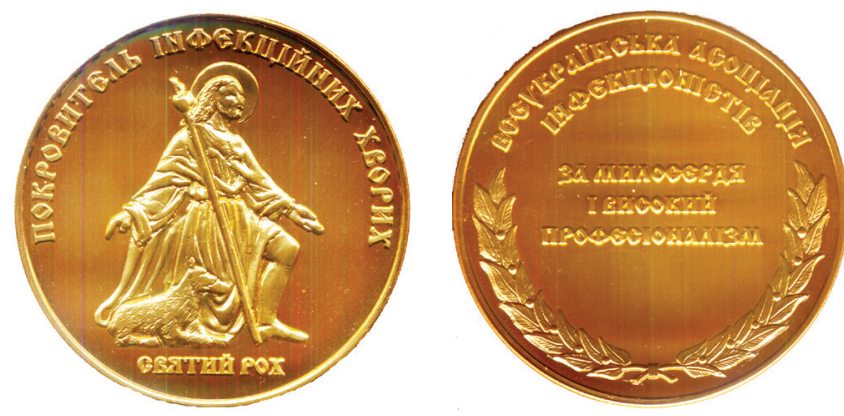

німбом, що вказує на святість зображеної людини. Покровитель присів на праве коліно. Його середньовічний одяг спадає до підлоги. Ліве коліно й гомілка оголені, що, за переказом, демонструє її ураження чумним бубоном. Перед Рохом стоїть довга палиця, верхній кінець якої спирається на праве плече святого. Біля ніг - собачка з куснем хліба в зубах. Саме вона, як свідчить легенда, принесла цю поживу Роху, що захворів тяжко на чуму. Над зображенням святого кружно напис «Покровитель інфекційних хворих», а під зображенням - слова «Святий Рох».

На реверсі, в його центральній частині, - напис у три рядки «За милосердя і професіоналізм», кружно у верхній частині - «Всеукраїнська асоціація інсрекціоністів», нижче півколом лаврові гілки. Обидві сторони медалі мають бортики. За нашими даними, у минулому в Україні настільні медалі Святого Роха не виготовлялись.
Медаль Святого Роха вперше була вручена нагородженим 7 жовтня 2015 року на 9-му з'їзді інсрекціоністів України, що відбувся на базі санаторію «Медобори», (м. Тернопіль). Іїі отримали медичні сестри з усіх областей, за винятком Кіровоградської області та АР Крим. Ось прізвища нагороджених: Мазурець В.С. (Вінницька область), Матяшова Л.Д. (Волинська), Гінц О.П., Темченко О.І. (Дніпропетровська), Кабальєро В.С. (Донецька), Бойко Л.В., Петрівська Л.С. (Житомирська), Бокотей Г.І., Єщенко М.Ю. (Закарпатська), Бондаренко Н.В., Костюк В.П. (Запорізька), Брицька Т.В. (Івано-Франківська), Ляпицька Н.М., Разбойнікова О.П. Сидоренко Т.С., Сухенко І.В. (Київ і область), Устинова Л.О. (Луганська), Віслапуу М.Л., Збишко К.І. (Львівська), Казачонок Н.Д. (Миколаївська), Кирилова О. В. (Одеська), Заєць Н.П., Оліфер С.А. (Полтавська), Богурська Л.М. (Рівненська), Метенко О.В., Шевченко Н.Л. (Сумська), Мовчан М.М., Сімеоніді В.Н. (Тернопільська), Астафр'єва Т.Є. Корягіна Л. О. (Харківська), Сокерчак А.Я. (Херсонська), Ващук Л.В. (Хмельницька), Міронова Н.І. (Черкаська), Дудук А.М., Параскинюк Н.М. (Чернівецька), Мисенко І.М. (Чернігівська область).

Медичні сестри прийняли нагороду з вдячністю і хвилюванням. Їх самовіддана високопрофесійна праця повинна служити молодшому поколінню фахівців взірцем для наслідування.

Отримано 12.05.2016 р. 